Department of Morphology (Prof. K. KuRosumi), Institute of Endocrinology and Department of Oto-Rhino-Laryngology (Prof. H. IsHII), School of Medicine, Gunma University,

Maebashi, Japan

\title{
Transmission and Scanning Electron Microscopy of the Human Ceruminous Apocrine Gland I. Secretory Glandular Cells
}

\author{
Kazumasa Kurosumi and Isuzu Kawabata*
}

Received April 13, 1976

\begin{abstract}
Summary. The secretory portion of the apocrine sweat gland of the human external auditory meatus which is also called the ceruminous gland was observed by transmission and scanning electron microscopy.

The secretory glandular cells contain a well developed smooth endoplasmic reticulum and Golgi apparatus. Cisternae of rough endoplasmic reticulum are of ten closely applied to large round mitochondria. These large mitochondria have no relationship to the secretory granules. Near the concave surface of the Golgi lamellae several tubules can be found. In these Golgi-associated tubules a dark substance may accumulate to form specific large dense granules. Many less dense droplets or vacuoles may appear in these dark prosecretory granules and become liberated from their surface. Vacuoles formed in this manner then migrate to the apical cell surface and often discharge their contents into the gland lumen by the mechanism of exocytosis. Also, some of these vacuoles may be released into the lumen by the pinching off of small protrusions of cytoplasm, that is, they are released by the so-called apocrine secretory mechanism.

Acid phosphatase activity was demonstrated not only in the dark prosecretory granules but also in clear vacuoles situated at the apical end of the cell and in the gland lumen. Such a histochemical finding may indicate that the secretory substance of the apocrine sweat gland may contain hydrolytic enzymes derived from lysosomes, which are the prosecretory granules of this gland, and these enzymes may play a role in dissolution and break down of the material extruded into the lumen by apocrine secretion. Apocrine secretory processes of various sizes were observed on the luminal surface with the scanning electron microscope.
\end{abstract}

The ceruminous gland in the external auditory meatus is one of the typical apocrine sweat glands, which otherwise are distributed in certain special regions of the human skin, such as the axilla, perianal region, mammary areola, and eye lid. Of these various apocrine glands, the axillary apocrine sweat glands were observed by Kurosumi et al. (1959), Charles (1959), Hibbs (1962), Yamada (1962), Yasuda et al. (1962), Biempica and Montes (1965), Munger (1965b), Hashimoto et al. (1966), Bell (1974) and Schaumburg-Lever and Lever (1975) with electron microscopes. The ceruminous gland has not been reported on so often and the report by one of the present authors seems to be the only paper ever published dealing with its ultrastructure in the human (KAWABATA, 1964), though Munger (1965a) has reported on the cat and monkey ceruminous glands. Because of technical limitations at the time when KAWABATA's paper was published, the findings in that paper were rather limited.

\footnotetext{
* Dr. Kawabata's present address: Department of Otorhinolaryngology, Faculty of Medicine,
} Tokyo University, Tokyo. 
However, we have recently observed the same tissue using improved techniques not only in thin-sectioning but also in histochemistry and scanning electron microscopy. These techniques brought about new findings on the ultrastructure of the apocrine glands of this particular skin region, and more advanced discussions on the secretory mechanism are now possible. Thus, some questions pertaining to the interrelationship between the lysosome and secretory substance, as well as the relationship between two different mechanisms of secretory discharge, that is the so-called apocrine (decapitation) and eruptocrine (exocytosis) mechanisms might be settled by these newly achieved observations.

\section{Materials and Methods}

All the tissues used in this study were obtained from 15 human subjects who were under general anaesthesia for major surgery of otitis media. The removed skin specimens of the external auditory meatus were cut into small pieces less than $1 \mathrm{~mm}^{3}$ and fixed in $2.5 \%$ glutaraldehyde adjusted to $\mathrm{pH} 7.4$ with phosphate or veronal buffer and made isotonic with $2.75 \%$ sucrose and were postfixed with $1 \%$ osmium tetroxide. Some specimens were fixed either with simple osmium solution of CAULFIELD (1957) or mixture of $2.5 \%$ glutaraldehyde and $2 \%$ osmium tetroxide (Kurosumi, 1970). Dehydration was carried out in ascending concentrations of ethanol, and specimens were infiltrated and embedded in either Epon 812 or a mixture of Epon and Araldite. Sections were cut with a glass knife on a Porter-Blum ultramicrotome MT-2B and stained with uranyl acetate and lead citrate, and examined with a transmission electron microscope, Hitachi HU-11D.

For histochemistry, a piece of tissue was fixed with $2.5 \%$ glutaraldehyde containing $0.1 \mathrm{M}$ cacodylate buffer ( $\mathrm{pH}$ 7.4) for $2 \mathrm{hrs}$ and then cut into very thin slices, rinsed in the same buffer containing $0.33 \mathrm{M}$ sucrose and incubated at $37^{\circ} \mathrm{C}$ for $15 \mathrm{~min}$ in Gomori's lead salt mixture containing sodium $\beta$-glycerophosphate for detection of acid phosphatase activity. After rinsing with $2 \%$ acetic acid they were postfixed with $1 \%$ osmium tetroxide, and then dehydrated and embedded as above mentioned.

For scanning electron microscope studies, the removed skin specimens were fixed in buffered $2.5 \%$ glutaraldehyde followed by $1 \%$ osmium tetroxide. They were dehydrated with ethanol and embedded in a mixture of styrene and n-butyl methacrylate. After polymerization, specimens were cracked with a razor blade to disclose the gland lumen. They were immersed in amyl acetate for $3 \mathrm{hrs}$ for the removal of the embedding media, and were critical point-dried using liquid $\mathrm{CO}_{2}$ with a Hitachi $\mathrm{HCP}-1$ dryer. Specimens were coated with carbon and gold in a vacuum evaporator and observed with a JEOL JSM-S scanning electron microscope.

\section{Observations}

\section{Transmission electron microscopy}

The secretory portion of the apocrine sweat gland has a relatively wide lumen surrounded by a wall consisting of two kinds of cells, one type is the secretory glandular cell and the other type is the contractile myoepithelial cell. The former forms a simple columnar epithelium, and the latter covers very tightly the glandular epithelium and makes a sheet called the myoepithelium (Fig. 1). A relatively thick 


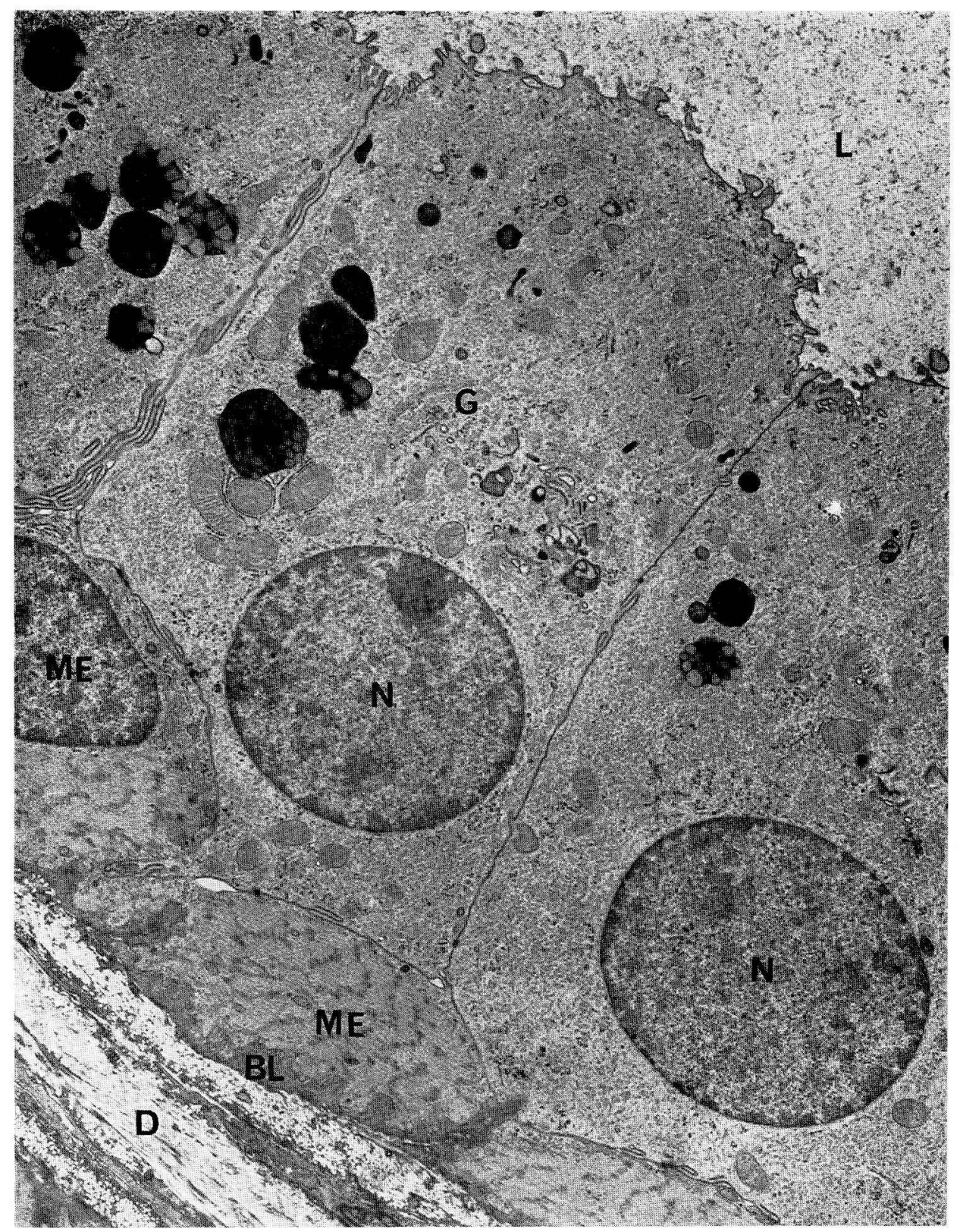

Fig. 1. Low magnification micrograph of the secretory portion of the ceruminous apocrine gland. The glandular cells are tall columnar cells bulging up into the lumen $(L)$. The round nuclei $(N)$ are situated near the cell base, which is covered with a sheet of myoepithelial cells $(M E)$. A thick basal lamina $(B L)$ invests the outer surface of the myoepithelium, and separates the tissue of the gland proper from the surrounding connective tissue of the dermis $(D)$. The gland cells contain large dense granules and a well developed Golgi apparatus $(G)$ at the supranuclear region, and a smooth endoplasmic reticulum fills almost all the cytoplasm. $\times 6,000$ 
basal lamina covers the outer surface of the myoepithelium and separates the glandular tissue from the surrounding connective tissue.

Although the secretory glandular cells and myoepithelial cells are clearly different from each other both in structure and function, the attachment of both cell types is very tight and complex, as shown in sections observed with the transmission microscope. There is almost no space left between the plasma membrane of the glandular cell and that of the myoepithelial cell. These two membranes of adjacent cells of different types are seen as parallel lines about $100 \AA$ apart from each other. At very few places these two membranes are separated from each other by a slightly widened intercellular space which looks clear as if it were empty. It is possible that such a clear space may be formed artificially by the shrinkage of cells during the fixation or dehydration procedure. In some parts of the cell boundary between the glandular and myoepithelial cells, the paired membranes may be simply folded. Such foldings or plications may occur on the lateral cell boundaries, between two adjacent glandular cells (Fig. 1), but these found in the ceruminous gland are less developed than those of the axillary apocrine gland as was previously reported (KuROsumi et al., 1959; KaWABATA, 1964).

The glandular cells are generally cylindrical in shape and their lateral boundaries

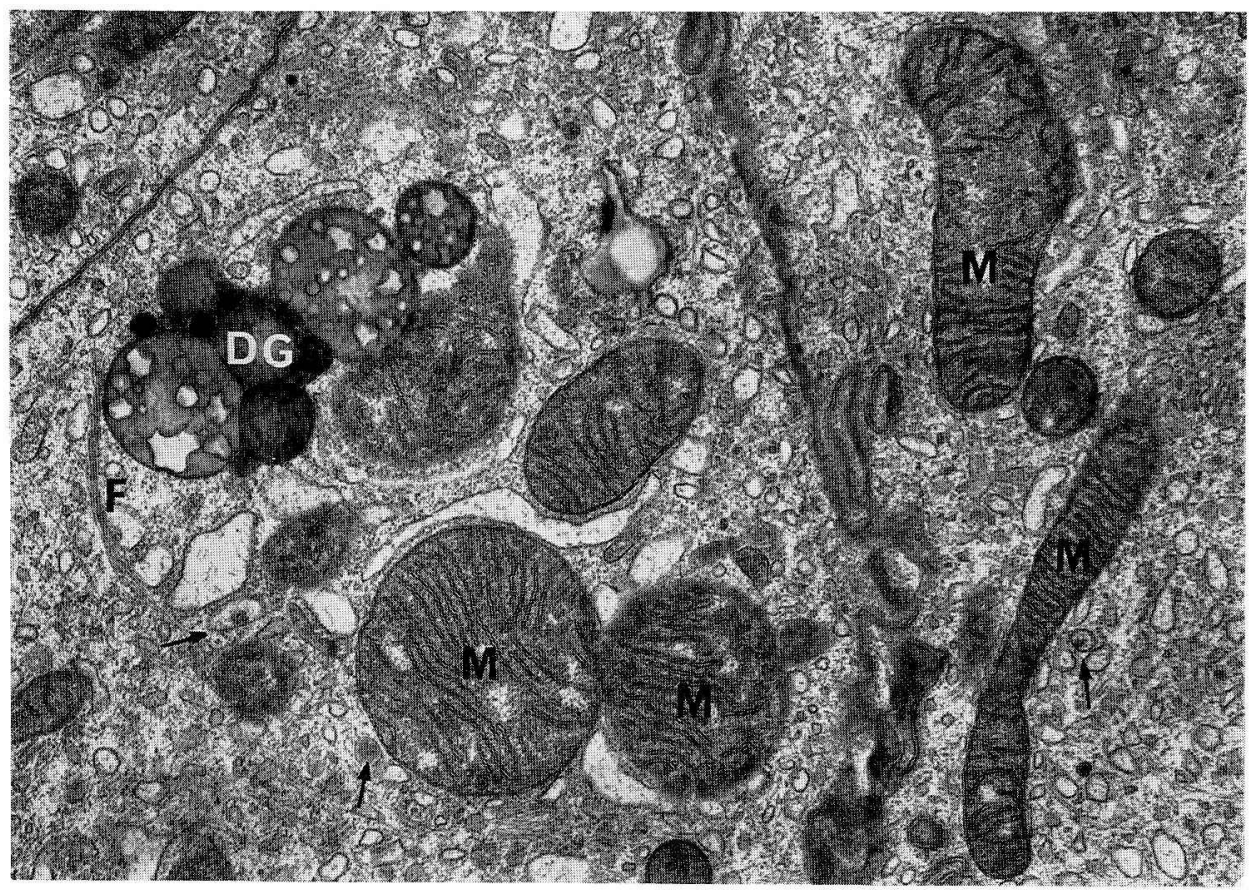

Fig. 2. Cytoplasm of the gland cells showing many mitochondria $(M)$, dense granules $(D G)$ and many tubular or vesicular cisternae of the smooth endoplasmic reticulum. Closely applied to some mitochondria are slightly dilated cisternae of the rough endoplasmic reticulum. Mitochondria of a slender form are of the usual size, but some round mitochondria are extremely large. Arcuate bundles of fine filaments $(F)$ are seen. Arrows indicate the accumulation of a dense substance in vesicles of the smooth endoplasmic reticulum. $\times 20,000$ 
are almost straight, though some plications do occur. Their basal surface is often indented by myoepithelial cells. Sometimes slender processes of cytoplasm are extended between adjacent myoepithelial cells. Desmosomes, though smaller than those in the epidermis, occur not only along the lateral cell boundary, but also between the glandular cell and myoepithelial cells (Fig. 1,5). A tight junction is observed at the extreme apical portion of the lateral cell boundary.

The apical surface of the secretory cell bulges up towards the lumen and small projections are abundant on the luminal surface. They correspond to the microvilli, but often are irregular in shape. The number and shape of microvilli vary considerably according to the functional states especially with those related to secretory discharge.

The nucleus of the glandular cell is regularly spherical and shifted to the cell base. The regularity of the glandular cell nuclei is strikingly in contrast to the elongate nuclei of the myoepithelial cells.

The cytoplasm contains various kinds of organelles such as the endoplasmic reticulum of both smooth and rough-surfaced types, Golgi apparatus and mitochondria as well as some inclusions, namely very dense granules (Fig. 1). The mitochondria in this secretory cell are highly variable both in shape and size. Some are slender filamentous while others are round; among rather small ones there occur huge ones. There are both small and large types of round mitochondria, but most of the slender

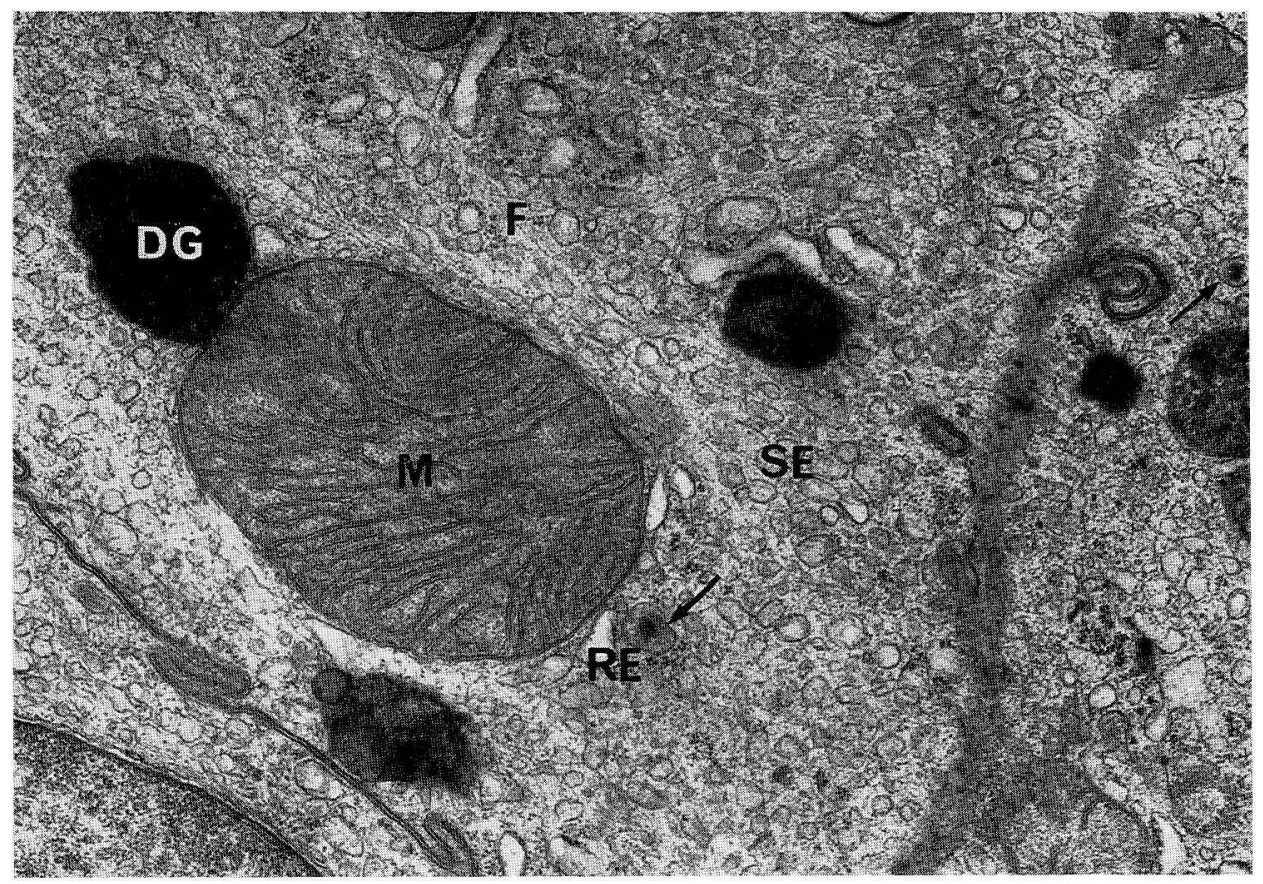

Fig. 3. Part of the cytoplasm of the glandular cells. A very large mitochondrion $(M)$ is observed. Closed to its surface there are slightly dilated cisternae of the rough endoplasmic reticulum $(R E)$ and several dense granules $(D G)$. The cytoplasm is filled with the cisternae of smooth endoplasmic reticulum $(S E)$ and fine filaments $(F)$. Arrows indicate vesicles containing dark cores $\times 20,000$ 
elongate mitochondria are not so large. On the other hand, some round or oval mitochondria are enormous in size and may have a diameter of five to seven times as large as the ordinary type (Fig. 2, 3). In both small and large mitochondria the so-called cristae or inner double membranes are well developed. Sometimes they may branch, but mitochondrlal granules are seldom observed. The matrix of the organelles is generally dark, though occasional clear spots are found which possibly represent artefacts. As almost no special accumulation of any kind was observed, probably the giant mitochondria are not the result of some pathological accumulation of some substance.

The endoplasmic reticulum of this cell type mostly consists of smooth-surfaced cisternae, which are either vesicles or tubules. They fill almost all available space in the cytoplasm. A few vesicles may contain a more or less opaque substance (Fig. 2, 3 ). Rough-surfaced endoplasmic reticulum is rather weakly developed and its components are typically cisternal or like irregular sacs. The cisternae of rough endoplasmic reticulum are often closely applied to large round mitochondria (Fig. 2, 3).

There are fine filaments forming bundles which are oriented in random directions in the cytoplasm. They look like tonofilaments from epidermal keratinocytes, but these found in the apocrine sweat gland cells are very small in amount, sparsely arranged and weakly bound together (Fig. 2-4). In Figure 4 we can see obliquely or

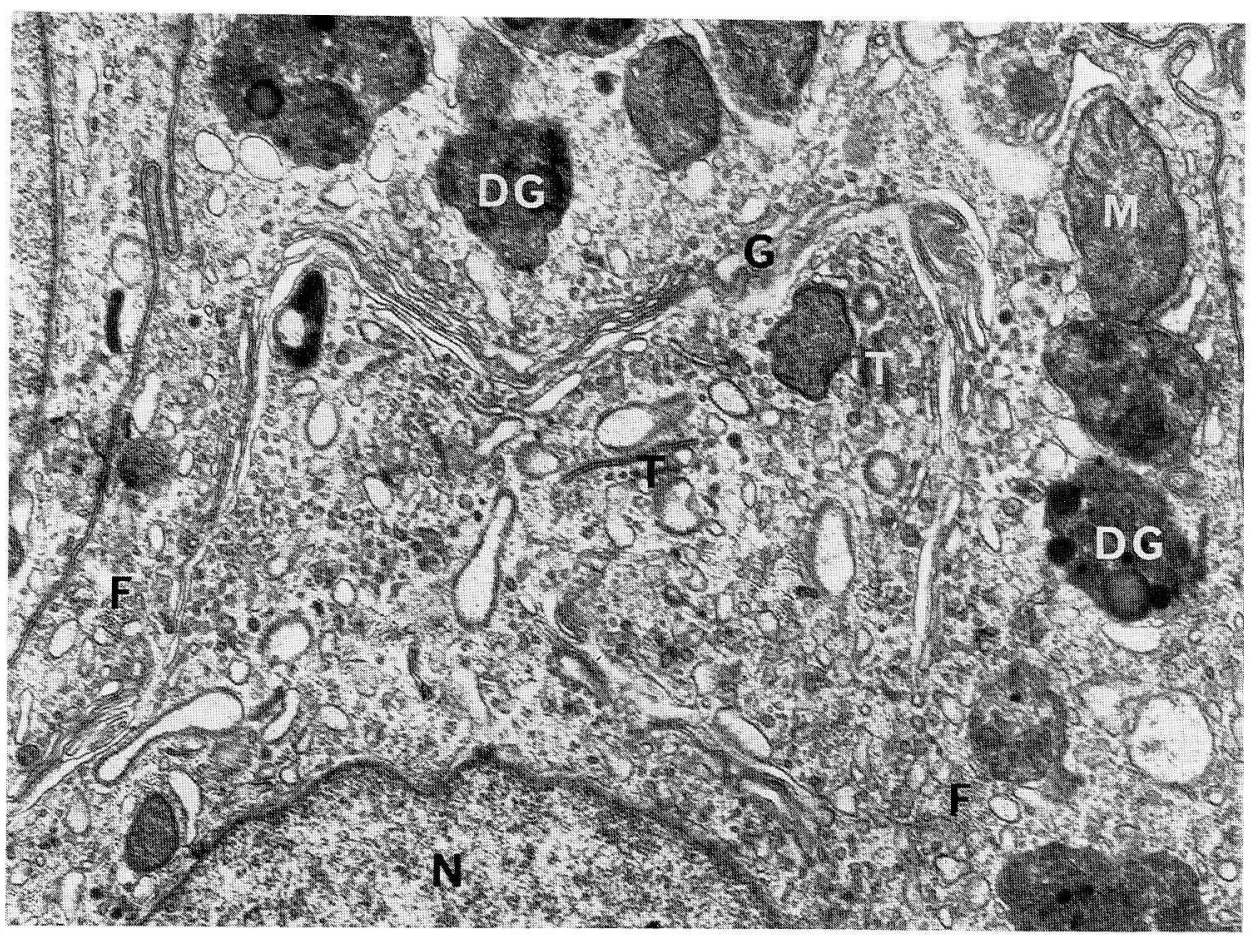

Fig. 4. Supranuclear area of a gland cell. A vast area above the nucleus $(N)$ is occupied by a well developed Golgi apparatus $(G)$, which is surrounded by many dense prosecretory granules (DG). Immature dense granules as well as specific tubules $(T)$ are seen inside the Golgi area. Mitochondria $(M)$ are situated at the periphery of the cell. Bundles of fine filaments are cross or obliquely cut $(F)$. 
cross cut bundles of filaments both inside and outside of the Golgi lamellae.

The Golgi apparatus of this cell is well developed and occupied a wide area the supranuclear region. Stacks of flattened sacs (lamellae) consisting of five or six sacs mark the external limits of the Golgi area. Many vesicles, with or without a bristlelike coating are gathered near the Golgi lamellae on both the internal and external sides. A short distance from the lamellae within the Golgi area a few tubules can be observed. Their caliber is about $170-200 \AA$, and their wall is thicker than the membrane of the Golgi apparatus proper and often has a bristle-like coating. These tubules are called Golgi-associated tubules and are thought to be the site of accumulation of dense material for the production of large dense granules which are especially numerous in the cytoplasm around the Golgi apparatus.

The cytoplasm surrounding the Golgi apparatus contains many large dense granules (Fig. 4,6). They are often so huge as to appear conspicuous even in the specimens observed by light microscopy, in which they have been called secretory granules. However, electron microscopy has never shown extrusion of such huge dense granules into the gland lumen. Therefore it does not seem suitable to call them secretory granules, but they may be called prosecretory granules, because they may give rise to less dense droplets which have been shown to be released into the gland lumen as described in detail in the later part of this paper. These dense granules have,

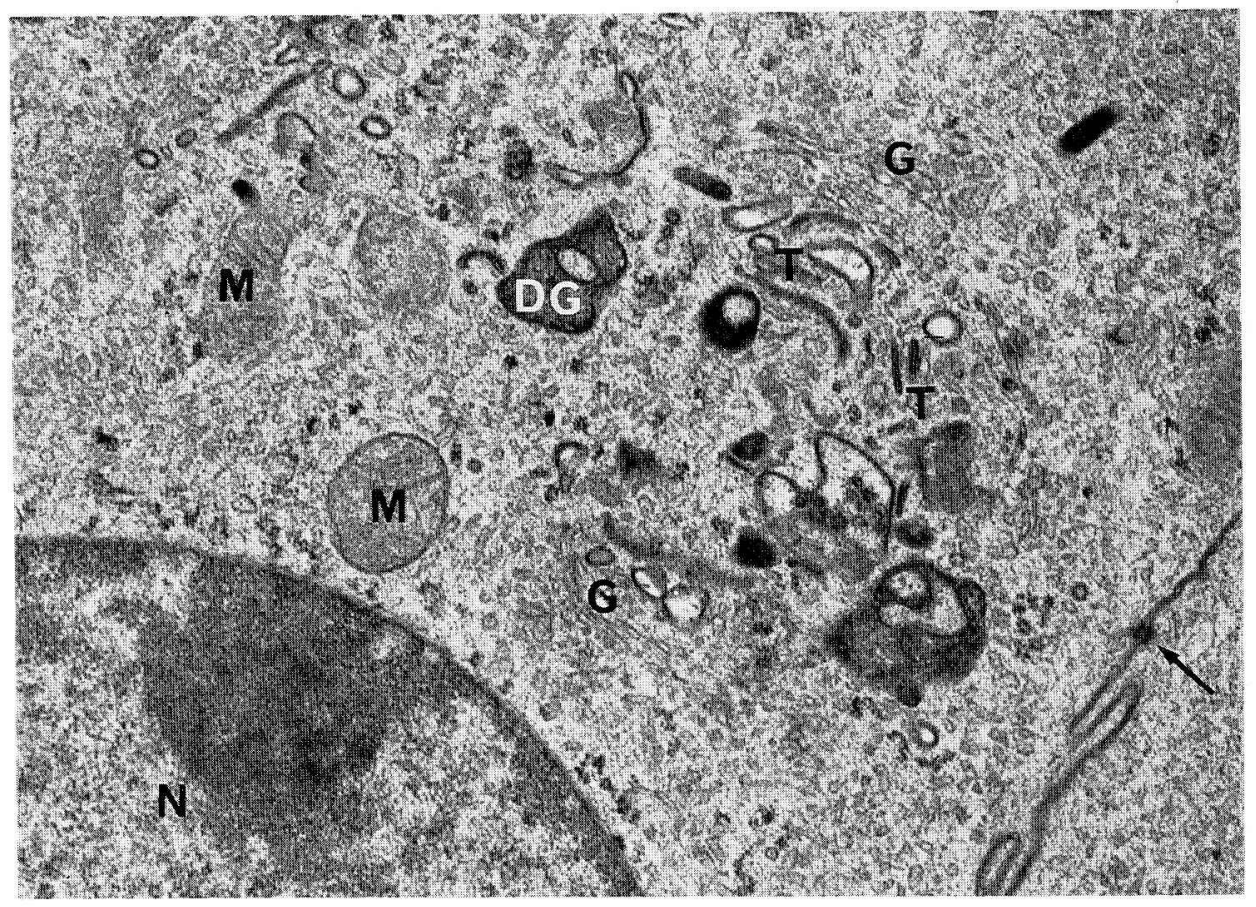

Fig. 5. A slightly higher magnification view of the Golgi apparatus and its surrounding area in a gland cell as illustrated in Figure 1. Stacks of Golgi lamellae $(G)$ outline the so-called Golgi area, within which tubules $(T)$ and irregularly shaped dense granules $(D G)$ are scattered. Mitochondria $(M)$ are also seen near the Golgi apparatus and the nucleus $(N)$. A poorly developed desmosome is indicated by an arrow. $\times 18,000$ 
without exception, a complex composition and contain many droplets of various densities. Frequently less dense droplets are situated on the periphery of the granule, more or less protruding from its surface (Fig. 6). As one can find such less dense droplets also outside of the dense granules, it is highly probable that they might be derived from the large dense granules. As the less dense droplets or vacuoles often accumulate along the luminal cell surface, it is thought that they are nothing but secretory granules, which will be extruded by exocytosis.

As mentioned above, unique tubules occur closely related to the Golgi apparatus

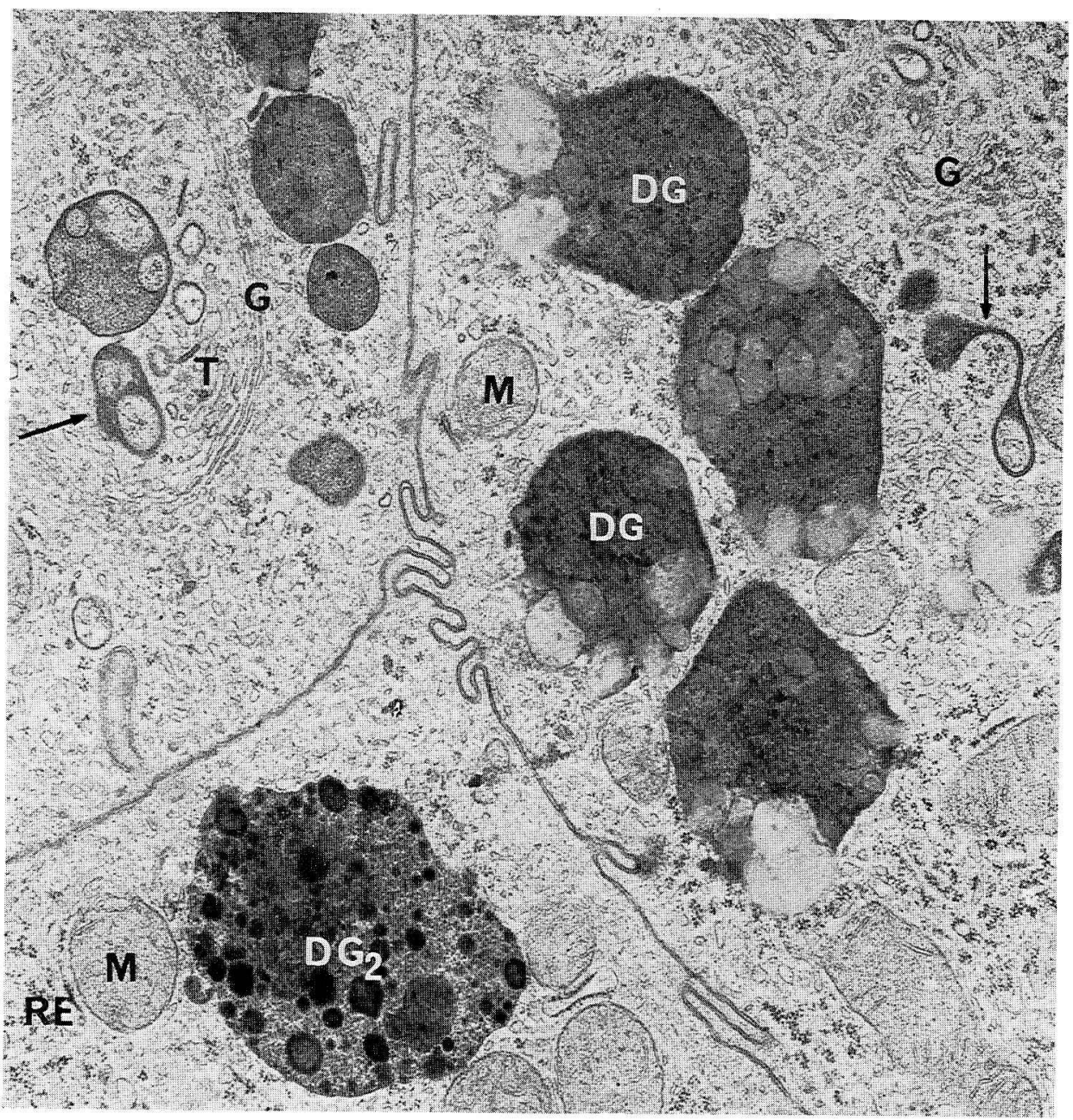

Fig. 6. Dense granules $(D G)$ of ceruminous gland cells as illustrated here are compound in structure, some of them contain both light and dark droplets. Near the Golgi apparatus $(G)$ immature granules are observed. They are probably formed by the accumulation of dense material (arrows) in the Golgi-associated tubules $(T)$. A dense granule seen at the bottom $\left(D G_{2}\right)$ is little different in structure from the rest of the granules. This granule contains very dense droplets but no large electron lucent droplets. Mitochondria $(M)$ and rough endoplasmic reticulum $(R E)$ are abundantly seen. The cytoplasmic matrix is filled with smooth endoplasmic reticulum. $\times 18,000$ 


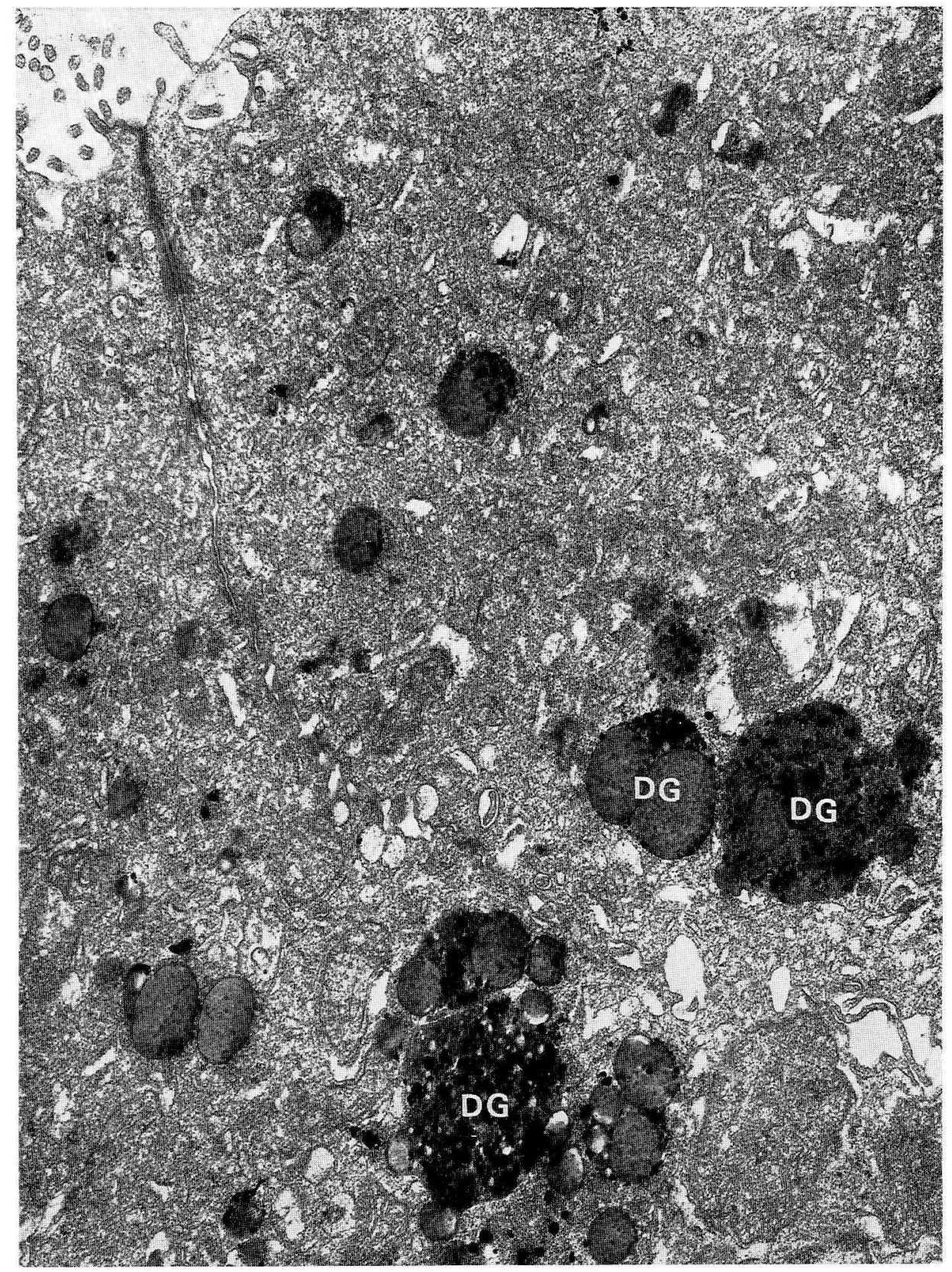

Fig. 7. Portions of the ceruminous gland cells after histochemical procedure for acid phosphatase activity. The reaction product is precipitated on the dense prosecretory granules $(D G)$ especially on the denser part of them, but there is little precipitate in the light droplets. $\times 13,000$ 
on its concave side. Within these Golgi-associated tubules dense substance may accumulate which may be an immature form of the dense prosecretory granules. Even in these small immature granules less dense vacuoles are often included (Fig. 5, 6). Droplets seen in these granules are variable in density, but most are not so dense. Small dense particles are also contained in the granules. Such heterogeneous structures of the granules are reminiscent of 1ysosomes seen in many other tissues.

There is another type of dense granules which look similar to the prosecretory granules, but differ slightly in detail. Droplets in such granules are denser than those in the prosecretory granules, but the matrix is much less dense (Fig. 6). This type dense granules are presumably non-secretory, because less dense secretory vacuoles are not found in them. Possibly they might also represent lysosomes.

In order to ascertain the nature of these dark granules, histochemical procedures to detect acid phosphatase activity were carried out. The reaction product was precipitated on almost all of the prosecretory granules, but the precipitates tended to appear over the dark matrix of these granules, very little reaction product was observed over the less dense droplets (Fig. 7). The acid phosphatase reaction product, however, may also appear in some vacuoles situated beneath the luminal surface. The precipitate was seen in the lumen especially along its peripheral part near the surface of the glandular cells (Fig. 8).

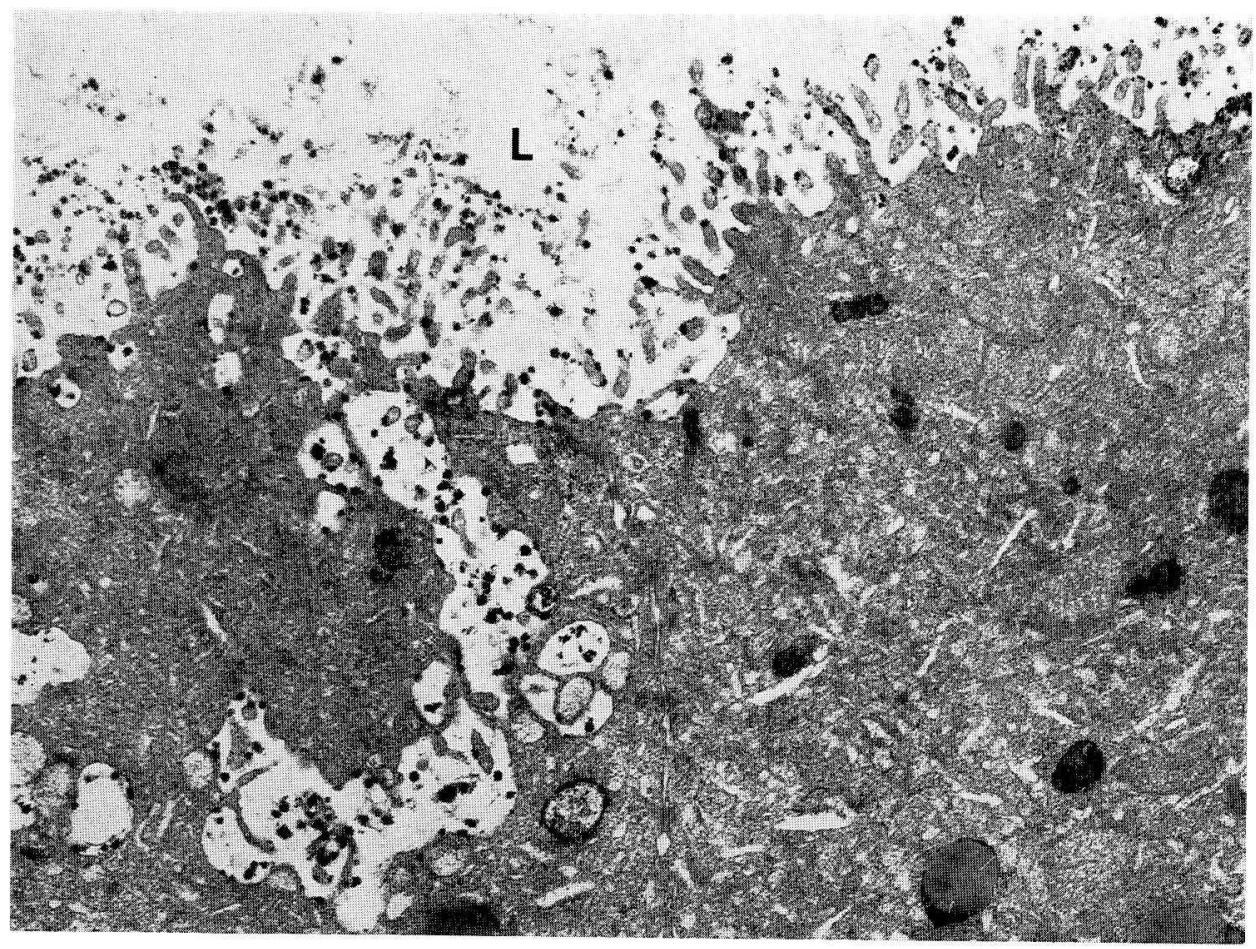

Fig. 8. Apical cytoplasm of the ceruminous gland cell facing the gland lumen $(L)$. Reaction products for acid phosphatase activity are precipitated not only on the dense granules, but also in the clear vacuoles occurring beneath the luminal surface as well as in the gland lumen, especially in the area adjacent to the gland cell surface. $\times 11,000$ 


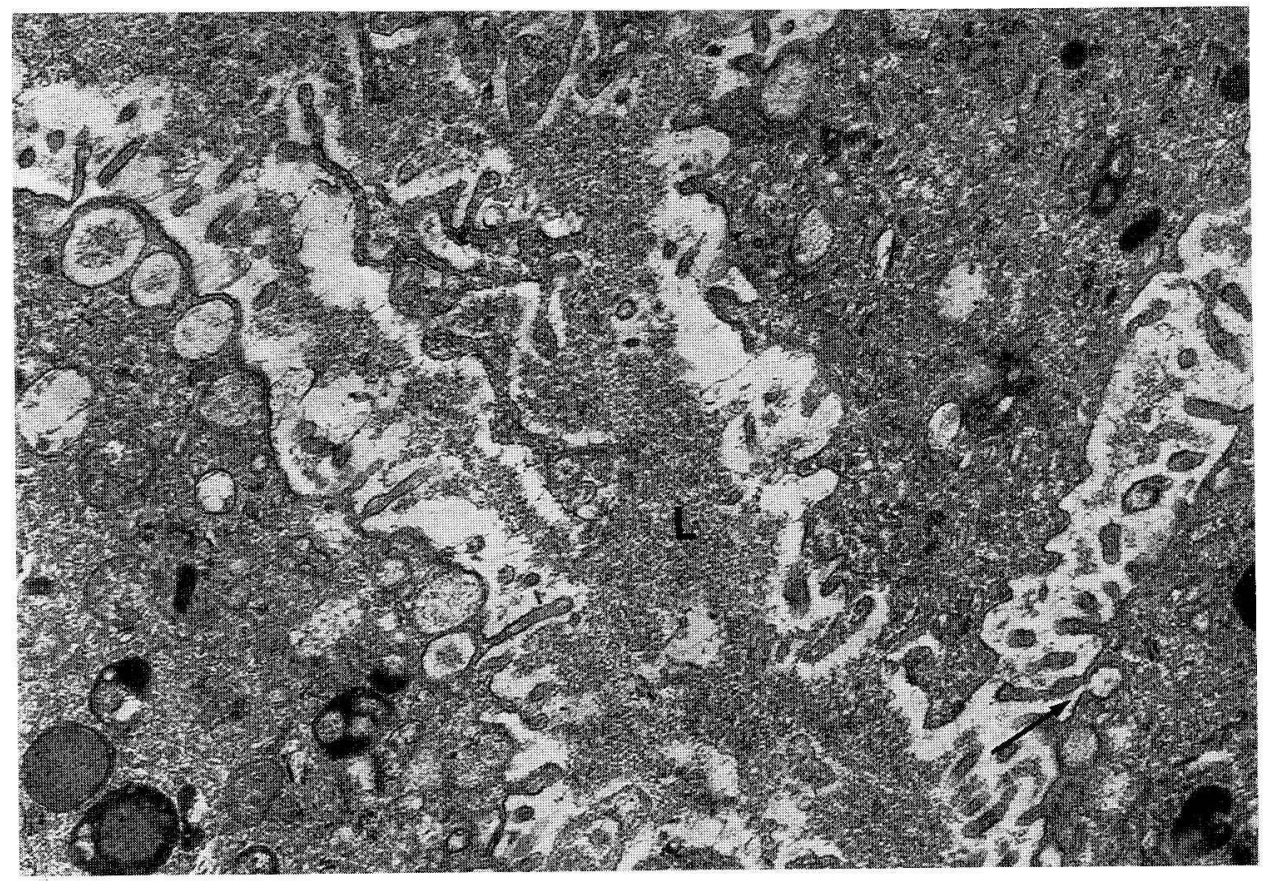

Fig. 9. The lumen $(L)$ of the ceruminous gland contains an amorphous substance probably produced by the breakdown of cytoplasm discharged by the apocrine mechanism. From the surface of the gland cells protrude many microvilli, and clear vacuoles probably derived from the dense prosecretory granules are accumulated just beneath the cell surface. An arrow indicates the opening of such a secretory vacuole into the lumen, suggesting the mechanism of secretion discharge. $\times 13,000$

The mechanism for extrusion of secretory substances from the ceruminous gland is rather complicated. As shown in Figure 9, the gland lumen is almost filled with a flocculent or filamentous substance. This substance in the lumen looks like the cytoplasmic matrix of the gland cells, suggesting that at least a small amount of cytoplasm may be released into the lumen. In this micrograph we can observe many vacuoles arranged along the cell surface, some of which are open to the gland lumen. This mechanism of secretion discharge is known as exocytosis or type IV extrusion (Kurosumi, 1961). The interior of these vacuoles looks empty in many cases, but some contain a flocculent substance similar in morphology to the luminal substance. Such a finding favors the view that the secretion may be discharged, at least partialy, by exocytosis in addition to the apocrine secretion.

The electron density of vacuoles or droplets arranged near the luminal surface of the glandular cells is variable, but most vacuoles contain a rather clear substance. Occasionally small round vesicles are contained in such clear secretory vacuoles (Fig. 10). The surface of the gland cell is often ruffled and many pit-like depressions are recognized, suggesting the exocytosis.

Sometimes a large bulbous projection may extend into the gland lumen. The interior of these projections are almost homogeneous and contain ordinary cytoplasmic matrix (Fig. 11). The base of the projection is constricted, suggesting a pinching-off 
separation of the process from the main cell body, known as apocrine extrusion, decapitation or the type II mechanism (Kurosumi, 1961). Smaller examples of these secretory projections are often observed. They look like polyps and are often pinched off (Fig. 12). Such a mechanism of secretion discharge is called the microapocrine

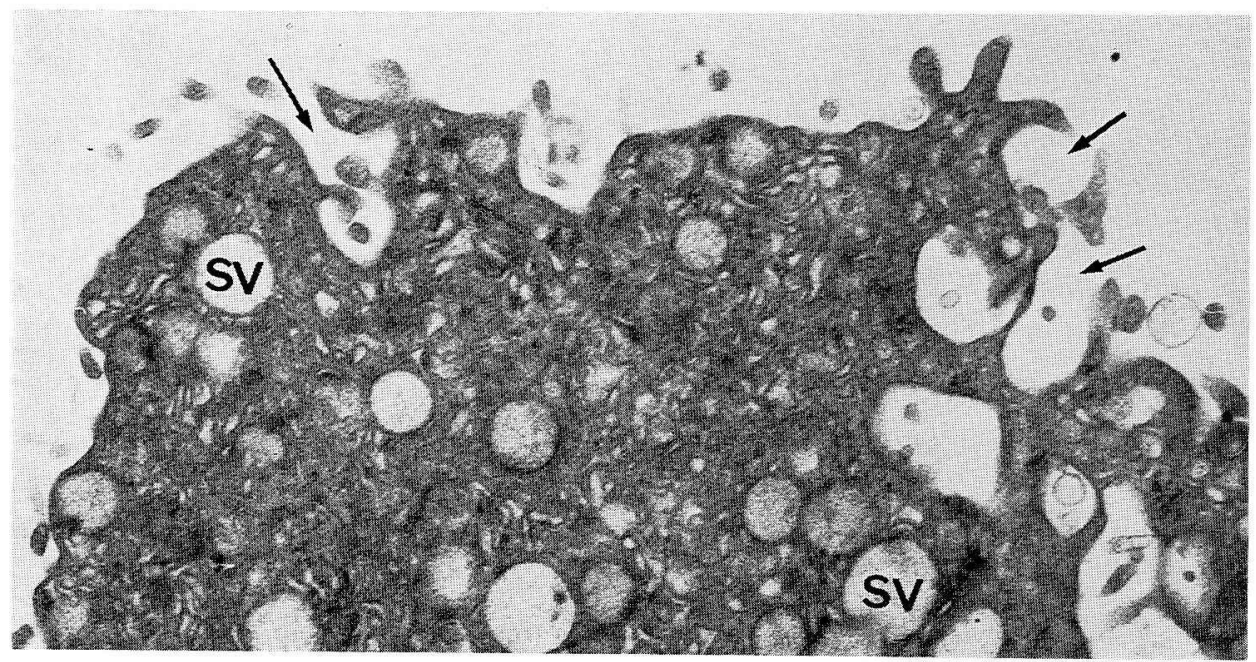

Fig. 10. Apical cytoplasm of a gland cell containing secretory vacuoles (SV) of variable density. Some of them contain small round grains or vesicles. On some places of its apical surface, many microvilli and round depressions are observed, suggesting the exocytotic release of the vacuole contents (arrows). $\times 18,000$

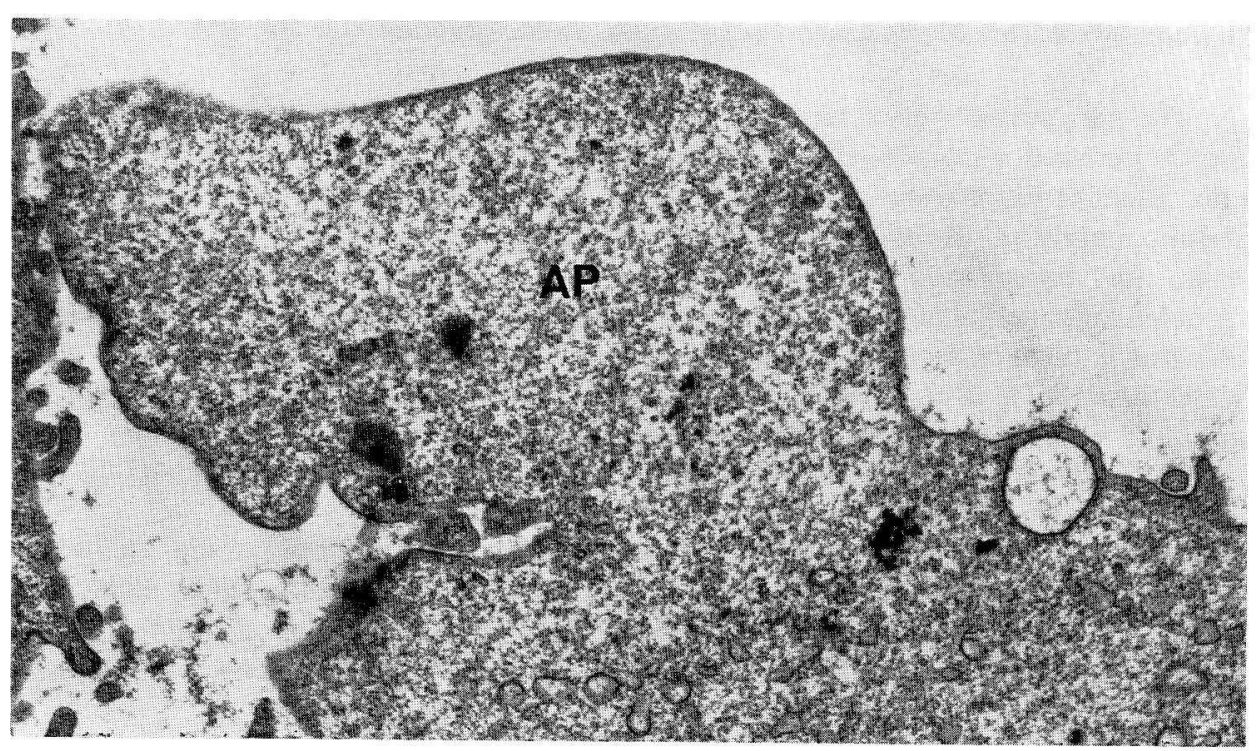

Fig. 11. A huge proccess $(A P)$ extending into the lumen of the ceruminous gland suggesting that it might be pinched off as the so-called apocrine secretion or decapitation. A small vacuole is seen on the right, probably just before the exocytotic release $\times 25,000$ 


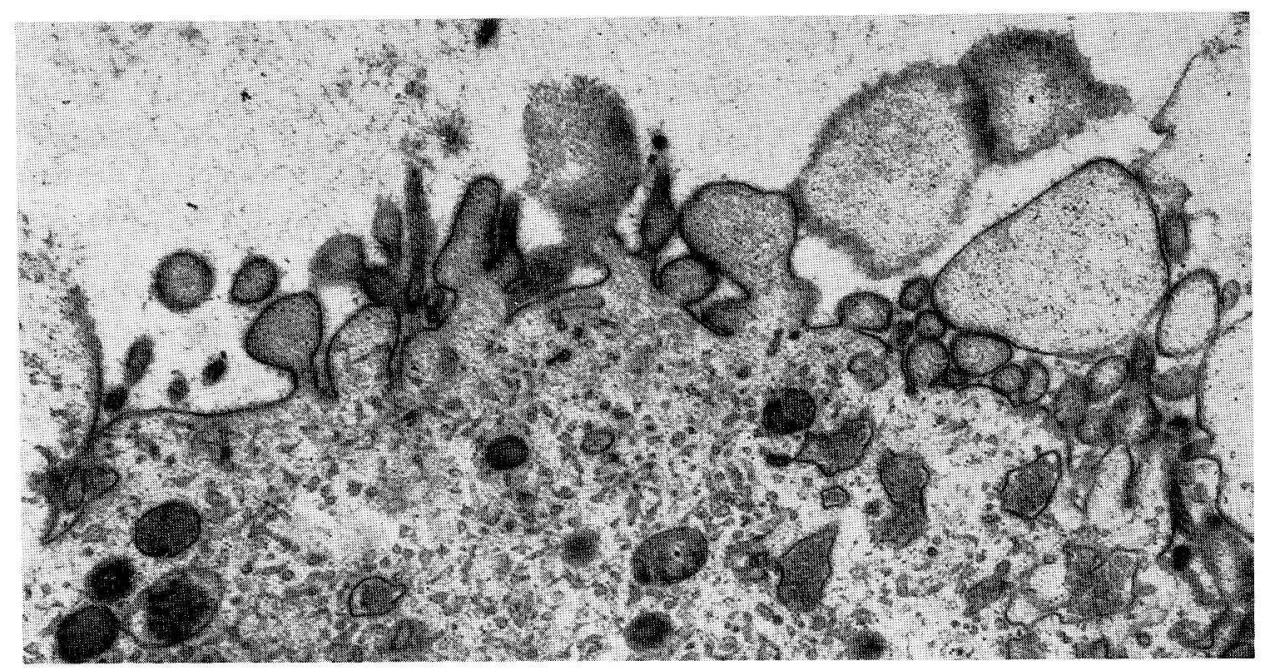

Fig. 12. Apical part of a gland cell of the human ceruminous gland. Polyp-like projections are gatherd on the free cell surface. They probably pinch off and this mechanism is called "microapocrine" secretion. $\times 15,000$

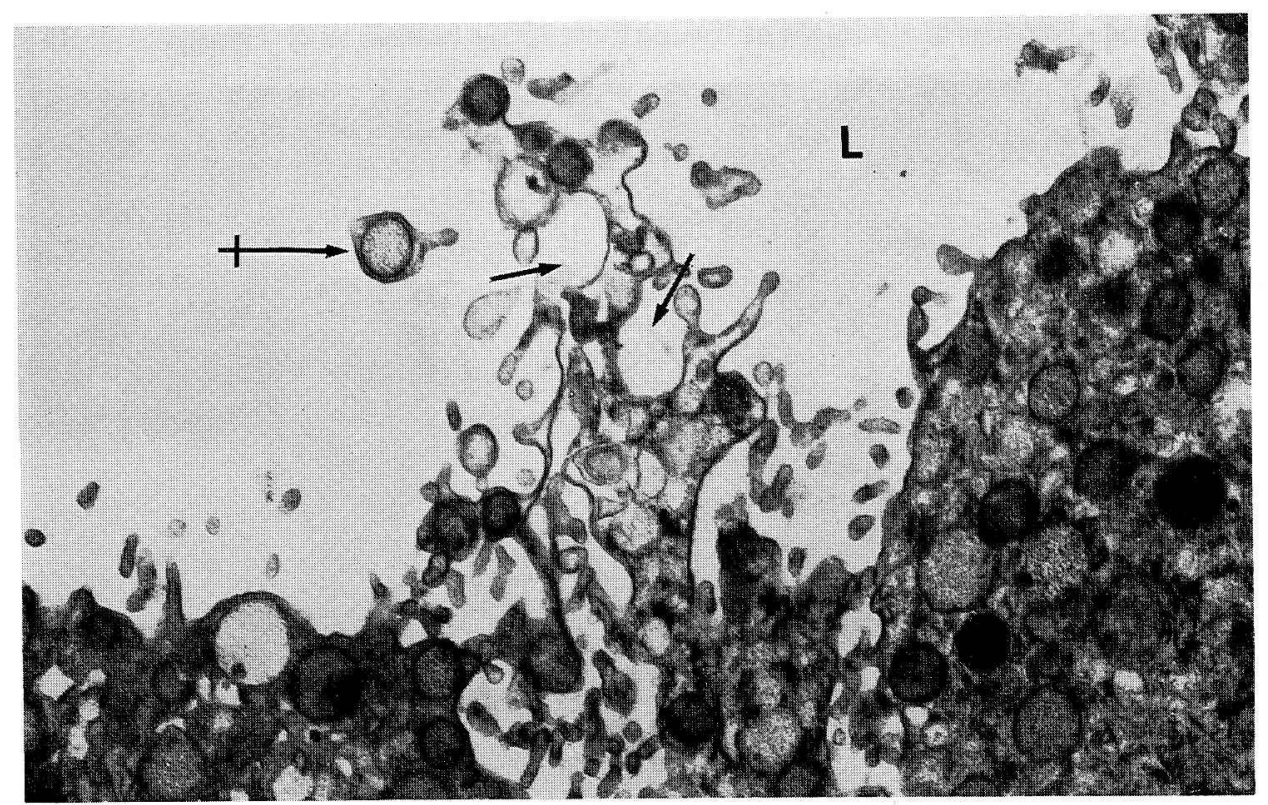

Fig. 13. Surface area of gland cells. A very large irregularly shaped projection is extended into the lumen $(L)$. Many secretory vacuoles and granules with various densities are accumulated not only in the cytoplasm of innert cells, but they appear also in the processes. Most of these secretory vacuoles may release their contents by the mechanism of exocytosis as indicated by an arrow. However, some granules may be released as a whole by the apocrine mechanism as they are covered with a small amount of the cytoplasm (crossed arrow). $\times 17,000$ 
mechanism and classified as type III extrusion. Both apocrine and microapocrine processes usually contain neither granules nor organelles, but in rare instances, secretory droplets or vacuoles are contained in an apocrine process and are pinched off from the cell body. Therefore some secretory droplets covered with a small amount of cytoplasm as well as a covering plasma membrane are sometimes found floating in the gland lumen (Fig. 13).

\section{Scanning electron microscopy}

In order to survey the extrusion of secretory substance from this gland threedimensionally, scanning electron microscopy of the luminal surface of the gland was carried out. As shown in Figure 14 a very large elevation of the surface is often observed on the glandular cells. They may be round like a dome or constricted at the base and look like an electric-light bulb. This configuration may be just before the detachment of the process from the main cell body. The surface of these processes is almost smooth, but some debris and cell fragments are attached. On the free surface of the glandular cell many slender microvilli were observed, but there were almost no microvilli on the surface of the processes (Fig. 14).

A balloon-like body seen in the gland lumen is illustrated in Figure 15. It has a very narrow stalk which is continous to the secretory cell body. The surface of the balloon is much smoother than those of secretory processes illustrated before. The extreme distention of surface plasma membrane at this stage of apocrine secretion may bring about the smoothness of the surface. The balloon may be separated soon
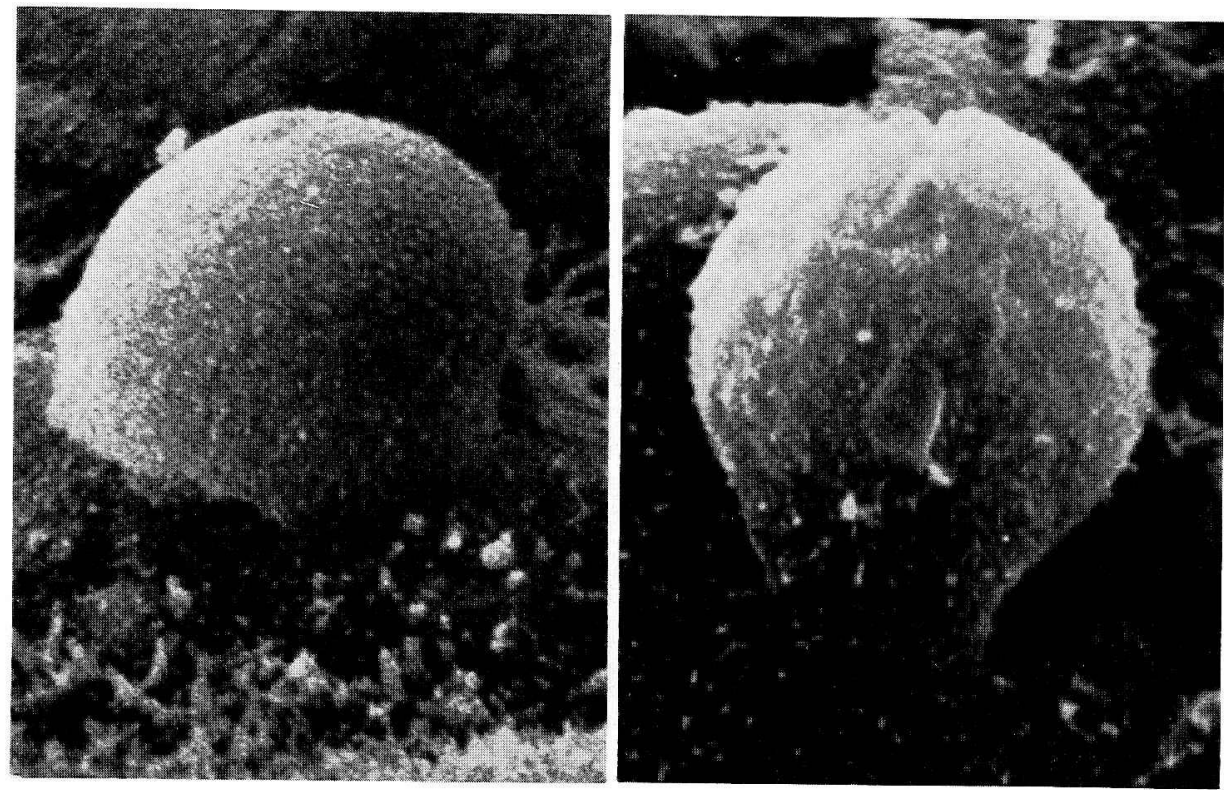

Fig. 14. Scanning electron micrographs showing large apocrine secretory processes elevated from the free surface of the ceruminous gland cells. The micrograph on the left shows the middle stage of the elevation of the secretory process, while the micrograph on the right illustrates the constriction of the basal part of the process shortly before the detachment of the process from the main cell body. Both $\times 6,000$ 
after from the cell body through severance of the stalk by a strong constriction of the surface membrane.

Sometimes one may find several small processes crowded on a single cell surface (Fig, 16). They are mostly ball-like and correspond to the microapocrine processes found in the transmission electron micrographs of thin sections. In Figure 17 two adjacent gland cells are illustrated, and their surface have a different appearance from each other. The upper cell has many microapocrine processes, while the lower cell has none but instead contains several pits on its surface. These pits probably result from the opening of secretory vacuoles into the lumen, indicating a secretory discharge by means of exocytosis.

\section{Discussion}

Electron microscopic studies on the apocrine sweat glands of the human skin have been almost entirely restricted to those of the axillary region. The first study was reported by TAKAHASHI (1957) and a little later Kurosumi et al. (1959) as well as Charles (1959) investigated the same material independently from one another. The latter two groups both described two kinds of secretory granules: dark and light granules dsecribed by us corresponded respectively to the rough and smooth granules

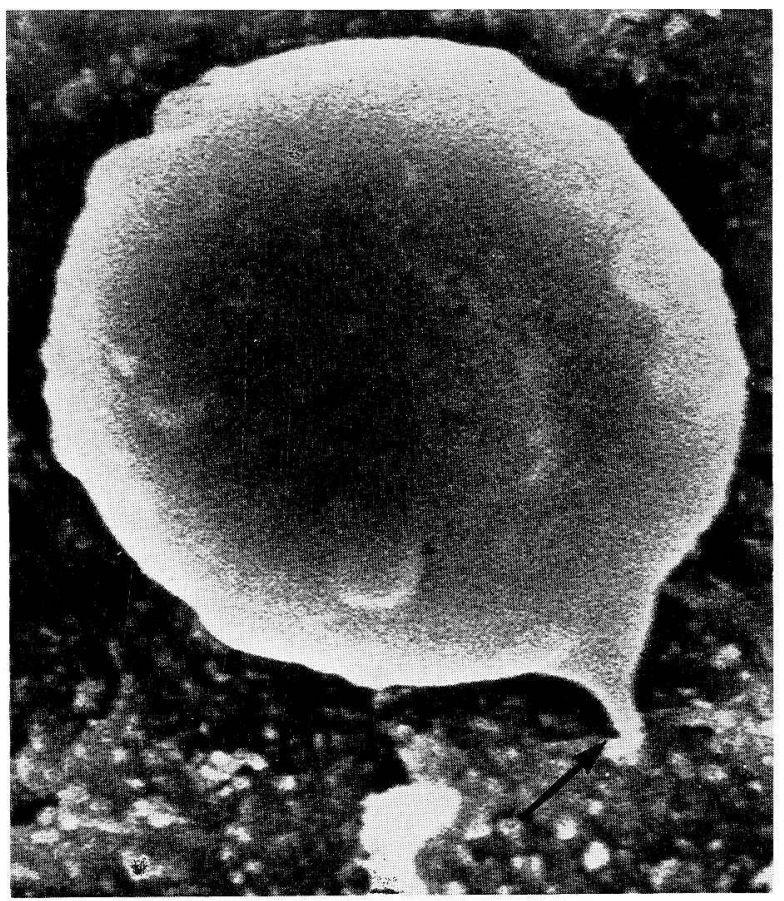

Fig. 15. Scanning electron micrograph of a huge balloon-like process from a glandular cell seen in the lumen of the ceruminous gland. The balloon-like body is connected to the luminal surface of a gland cell by a very slender stalk (arrow). It may be possible that the stalk is going to break by a constrictive movement of the cell surface membrane and the balloon may separate later from the cell body. $\times 16,000$ 


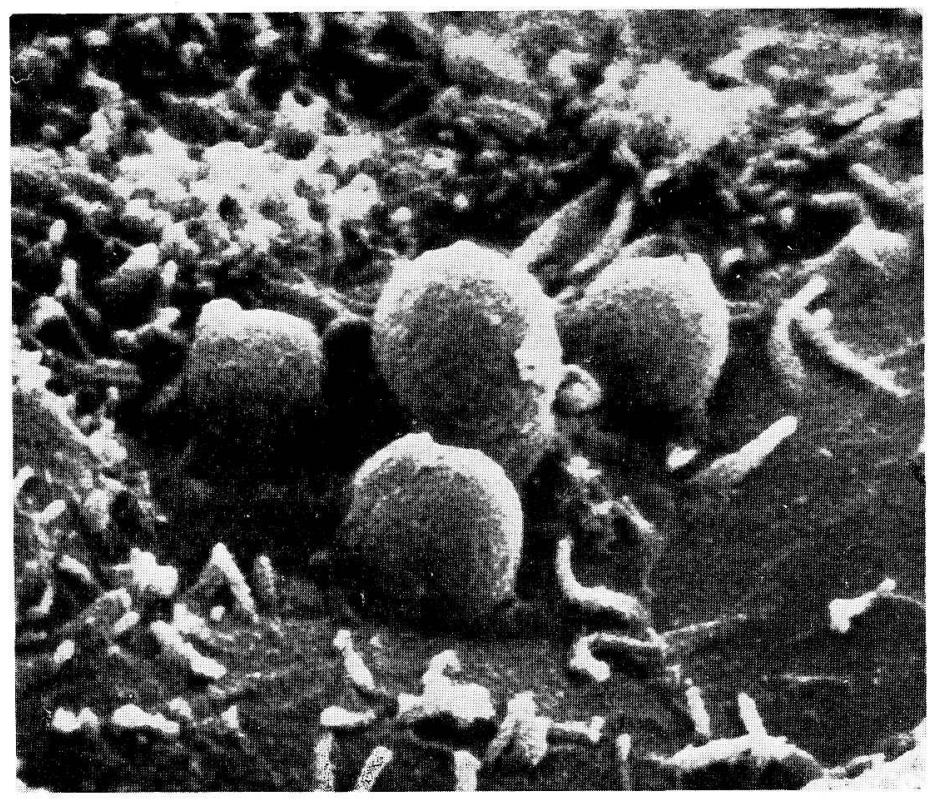

Fig. 16. Scanning electron micrograph of the luminal surface of a gland cell in the ceruminous apocrine gland. Four round processes are extended from one cell surface, suggesting microapocrine secretion. The numerous long rod-like processes are microvilli. $\times 6,000$

of Charles. We argued that the dark granules might be produced in the Golgi apparatus or smooth endoplasmic reticulum, but the light granules might arise from mitochondria. This view was later supported by Hasнiмото et al. (1966). The wide variation in shape and size of the mitochondria was noticed by several authors, including CHARLES, but he discounted the possibility that mitochondria might transform into the smooth (light) secretory granules, and this view was supported by some later researchers such as Y AMADA (1960), HibBs (1962), YasudA et al. (1962) and KAWABAT A (1964). The present research on the ceruminous gland also demonstrates the presence of giant mitochondria, but no proof of their transition into secretory granules has been forthcoming. Therefore we have discarded the old notion that mitochondria might give rise to secretory granules.

Kurosumi et al. (1959) considered that the two types of granules, the dark and the light, were produced by different cell organelles and were therefore not related to one another. CHARLES (1959) speculated that the smooth (light) granules might change to the rough (dark) granules, though he did not show convincing micrographs. YAMADA (1960) described three types of granules in the same gland, which might indicate three different steps of granule maturation. His $\mathrm{G}_{1}$ granule was a small immature one, while $G_{2}$ was large and full grown and the $G_{3}$ he described might have been formed by the break down of a portion of the $\mathrm{G}_{2}$ granules especially their protruding less dense parts. The so-called $\mathrm{G}_{2}$ granules are those we here call prosecretory granules and YAMADA's $G_{3}$ granules correspond to the less dense droplets or vacuoles we find chiefly accumulating in the apical cytoplasm. 
Hibis (1962) studied the axillary apocrine glands of Negro skin, and described two kinds of granules, which were thought to be transitional. He conjectured that the secretory granules might be formed as "light-staining condensations of material" in the Golgi area, and changed into dark granules: finally they might break up and go into solution in the apical cytoplasm and might pass through the cell membrane in the form of "small droplets." It is not clear, however, whether the droplets that he presumed are the same as the apical droplets found in the present study. He could not demonstrate the secretion discharge by the mechanism of exocytosis.

YASUDA et al. (1962) examined the axillary apocrine glands of Caucasian and Negro subjects and made detailed discussion about granules and vacuoles of the gland cells. They classified the cytoplasmic vacuoles into four different types, but they might include multivesicular bodies and lysosomes. They noticed huge mitochondria whose cristae had almost disappeared, but they denied that mitochondria were converted into the so-called light secretory granules.

One of the present authors, KawA-

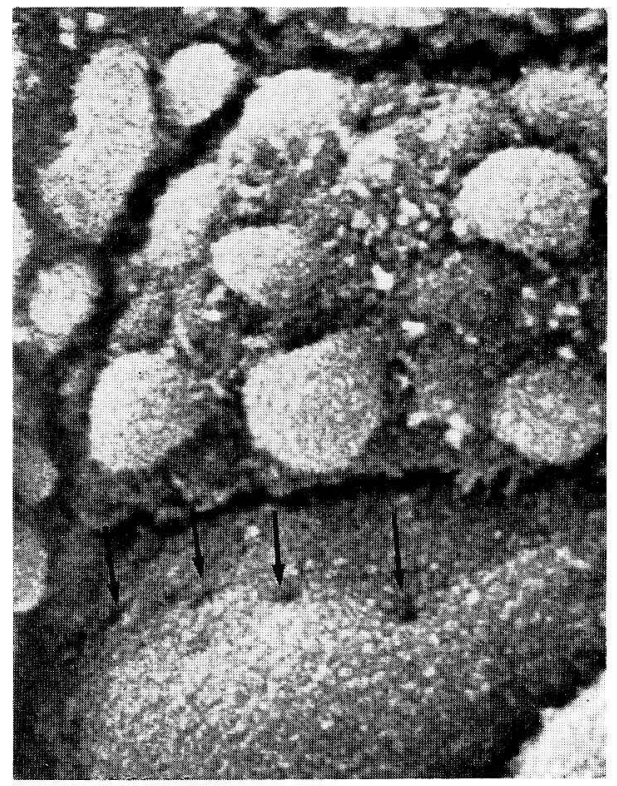

Fig. 17. Scanning electron micrograph showing the luminal surface of ceruminous gland cells. Extending from the surface of cells seen in the upper part of the micrograph, round microapocrine processes are evident; while on the cell surface seen below, several small pit-like depressions (arrows) are present. These pits are thought to be holes resulting from the opening of secretory vacuoles onto the cell surface, indicating the mechanism of exocytosis. $\times 4,500$ BATA (1964) was the first to observe the apocrine gland of the external auditory meatus, the ceruminous gland, under the electron microscope. Here also enlargement of mitochondria was noticed, but this phenomenon may be unrelated to secretory function. He demonstrated, however, the presence of large round vacuoles near the free surface of the gland cell. These vacuoles were often associated with a crescent dark rim which suggested the origin of vacuoles from the so-called dark granules; the vacuoles were so closely situated to the surface plasma membrane that these vacuoles were thought to burst open to the lumen and discharge the content (KAWABATA, 1964). His conjecture that the dark granules might give rise to less dense vacuoles which in turn open to the luminal surface for discharge has been supported by our observations in this paper. Thus we prefer to call the dark granule the "prosecretory granule" instead of secretory granule, because the dark granule itself is not released, but produces lucid droplets or vacuoles which may be the actual secretory product.

MungER (1965b) studied the human axillary apocrine gland and presumed that the dense granules may be keratin. He arrived at this conclusion from the finding that delicate less dense filaments were embedded in the dense matrix of the granule which appeared to have the so-called keratin pattern found in epidermal and pilary keratin, 
and that these granules were positive for SH and SS groups by light microscopic histochemistry. In the present study, however, no filamentous structures in the dense granule suggestive of keratin were found in the human ceruminous gland. MUNGER demonstrated less dense vacuoles near the apical surface of the secretory cell and assumed they might be released by exocytosis, but he never found any relationship between dense granules and less dense vacuoles.

As reported in a recent paper of BELL (1974), three different types of so-called secretory granules are found in the human axillary apocrine gland. She observed filaments both in her type I and II granules but denied the possible presence of keratin in these granules. Both in the axillary and ceruminous apocrine glands of Japanese subjscts we (Kurosumi et al., 1959; Kawabata, 1964; as well as the pressnt observation) could find granules corresponding to these three types of granules described by BELL (1974). Her type I granules are nothing but the dense prosecretory granules as reported here which are assumed to give rise to less dense secretory vacuoles. These vacuoles have been demonstrated by authors such as YAmAdA (1960), MunGer (1965b) and Shaumburg-Lever and Lever (1975), however Bell (1974) did not refer to these less dense vacuoles or droplets. She thought that small cored vacuoles called type III in her paper might be the precursors of type I granules. The same idea was already published by Kurosumi et al. (1959) and also in the present study such cored vacuoles have been observed in the ceruminous gland. However, the main source of the dark prosecretory granules is undoubtedly the Golgi-associated tubules, and cored vacuoles are not found in the Golgi zone but in the more basal part of the cell as BELL also indicated. Therefore, the direct transformation of cored vacuoles into dark granules is still in doubt, but the accumulation of such dark substance in the cisternae of the smooth endoplasmic reticulum may be related to the production of some constituent material of secretion of this gland.

Neither MUnGer (1965b) nor BeLl (1974) paid any consideration to the possibility that the dense granules in human apocrine sweat glands might be related to lysosomes. We recognized a positive reaction for acid phosphatase activity in dark granules which correspond to the type I and type II granules of BELL (1974). But as her type II granules are rather rarely observed and do not contain protruding less dense vacuoles as in the type I (our prosecretory) granules, we consider that the so-called type II granules may be the true lysosomes and not directly related to the formation of secretory granules (or vacuoles) in this gland.

As mentioned above the dark granules in this gland are nothing more than lysosomes as we have demonstrated in the present paper; this possibility was already pointed out by KAwABATA in 1964 on purely morphological grounds. Then BiEMPICA and Montes (1965) as well as Hashimoto et al. (1966) succeeded in the histochemical demonstration of acid phosphatase activity in the dark granules of the human axillary apocrine glands. Besides these lysosomal dark granules, vacuoles arranged beneath the luminal surface were demonstrated by both these groups. They thought that the material in these vacuoles might be released in some way, but they both did not observe the actual act of extrusion. Furthermore, they were puzzled about the possible relationship between the dark lysosomal granules and clear vacuoles, although the authors in both papers assumed that the dark granules might be disintegrated in the apical cytoplasm. Y AMADA's idea (1960) that these vacuoles might be protruded from 
the dark granules was only a speculation, but it has now been proven true by us.

We found features suggesting the separation of the less dense droplets or vacuoles from the preexisting dark granules, and in fact many vacuoles situated in the apical cytoplasm have a dark rim which is frequently shaped like a crescent; this may be a remnant of the dark substance from the lysosomal prosecretory granules still attached to the vacuoles. Furthermore, the exocytosis of such vacuoles was clearly observed in our present study. Therefore, the entire process of maturation and discharge of secretion has been elucidated, from the dark lysosomal granules to the extrusion of material into the lumen from less dense vacuoles derived from the dark granules. Peculiar Golgi-associated tubules are closely related to the production of these dark prosecretory granules. It is most probable that these tubules may be identical with the so-called GERL of NovikofF and his coworkers $(1964,1971)$. In a similar way to their argument that the GERL may produce lysosomes and sometimes secretory granules, we may postulate that the dark substance is accumulated in some portions of the Golgi-associated tubules. Histochemical electron microscopy performed in this material clearly demonstrated that the dark prosecretory granules of this gland are nothing more than lysosomes in accordance with the report of BIEMPICA and MonTEs (1965). Moreover, it was observed that the hydrolytic enzymes represented by acid phosphatase are undoubtedly released into the gland lumen. Such secreted enzymes may actively digest the protoplasmic debris extruded by the apocrine mechanism (decapitation) of secretion.

Charles (1959) referred to the partial break down of surface plasma membrane of the gland cells and presumed that the cytoplasm might flow out. Such a process is not apocrine secretion, but it is undoubtedly an artefact caused by inappropriate fixation or dehydration. Yamada (1960), Biempica and Montes (1965) as well as Munger (1965a, b) spoke against the existence of an apocrine mechanism, but we frequently observed such a mechanism of secretion discharge. Various sized processses, some of which are round ball-like and others irregularly shaped and tongue-like, may protrude from the glandular cell surface into the lumen. These processes may be released by constriction at their base. Sometimes a special layer for detachment called a demarcation membrane (or layer) may be formed at the boundary between the process and the main cell body, and the process may separate at the membrane (Kurosumi et al., 1961). Such a mechanism is often called "decapitation" by dermatologists and is classified as the type II mechanism of secretion discharge (KuROsumI, 1961). A smaller dimension of this extrusion mechanism is frequently reported and is called "microapocrine" or type III secretion. Both of these types are observed in the human ceruminous gland along with the so-called exocytosis that is type IV extrusion according to our classification (Kurosumi, 1961). Наsнimoto et al. (1966) agreed with us concernig multiplicity of the secretory mechanism of the apocrine sweat gland, and they suggested the real existence of the decapitation mechanism. Among animal apocrine sweat glands such as rabbit (Kurosumi et al., 1961), horse (Kurosumi et al., 1963; Sørensen and Prasad, 1973) and lemur (Kneeland, 1966), the true apocrine mechanism was reported, though there was one opposing view (HEATH, 1974 in rabbit glands). In the rat mammary gland BARGMANN and his associates (BARGMANN and KNOOP, 1959; BARGMANN et al., 1961) repeatedly argued that the socalled apocrine mechanism described in light microscopy might be an artefact during 
specimen preparation, but we observed every step of the formation and detachment of apocrine processes containing lipid and proteinous secretory granules in the mammary gland of lactating rats (KuRosumi et al., 1968). The protein secretory granules of the rat mammary gland may be released by two ways, one is exocytosis and another is apocrine mechanism. In the present study we proposed that the less dense vacuoles of the ceruminous gland may also be extruded by two ways, just like the mammary gland.

Recently Schaumburg-Lever and Lever (1975) again demonstrated multiplicity of the secretion mechanism of the apocrine gland in the human axilla, showing three possibilities: merocrine (exocytosis), apocrine and holocrine. Except in the last case, all of their assumptions, have been proven by our present observations on the ceruminous apocrine gland. Though they did not refer to the formation of secretory vacuoles (called vesicles in their paper), they presented clear evidence for exocytosis by these vacuoles as we have shown with the ceruminous gland in this paper.

Concerning the apocrine mechanism or so-called decapitation, ScHAUMBURG-LEvER and LEVER (1975) showed a distinct membrane structure dividing the secretory process and the main cell body, which is similar to that shown in the apocrine gland of the rabbit chin in an older paper of ours (KuRosumi et al., 1967). However, they observed a tubulous clear space continuous to the lateral cell surface just above the dividing membrane, and concluded that these tubules might be fused to each other and result in the detachment of the so-called apocrine cap (secretory process) from the cleft formed by the fusion of tubules but not at the place of dividing membrane (demarcation zone). The micrographic evidence demonstrated in their paper was very convincingly arranged, but we think that the tubules found above the dividing membrane are merely profiles of cell cleft at the constricted part of the apocrine process, because some microvillous projections can be observed on these so-called tubules. The separation of the process may occur along the dividing (demarcation) membranes also in this case, but these were not found in the ceruminous gland.

As to the breaking down of cells for secretory discharge, i.e., the holocrine mechanism, one must be very careful to distinguish the natural disintegration of cells from artefacts.

CHARLES (1959) reported that the human axillary apocrine glands were provided with intercellular canaliculi. Judging from the electron micrographs in his paper, it is clear that the canaliculi mentioned by him are nothing more than a narrow moat between the apical elongations of gland cell cytoplasm. In his micrographs the socalled canaliculi were never shown as round cross-cut profiles, but they are always elongate, even in a section cut transversely through the apical part of the gland cells. It was later made evident that the intercellular canaliculi occur only in the eccrine sweat glands between the adjacent basal clear cells. No reports other than the one by CHARLES have referred to the canaliculi in the human apocrine sweat gland, but in the glands of the lemur antebrachial organ true intercellular canaliculi have been observed by KNEELAND (1966). He stated that the organ had the characteristics of both apocrine and eccrine sweat glands. The intracellular canaliculi found in the horse sweat gland (SøRENSEN and PRASAD, 1974) represent a special case. It is known, however, that the sweat glands of the general body surface of the horse are morphologically apocrine but their function resembles the eccrine sweat glands of the human 
body (KuRosumi et al., 1963).

The folding of the basal plasma membrane is one of the salient features of the mammalian sweat glands. It was first reported by TAKAHASHI (1957) in the human apocrine sweat gland and then in the eccrine sweat gland of the pig (carpal organ) by Kurosumi and Kit Amura (1958). We further demonstrated the basal foldings in the eccrine and apocrine sweat glands in man (Kurosum et al., 1959; 1960). In the rat plantar eccrine sweat gland, MatsuzawA and KuRosumi (1963) demonstrated strong activity of alkaline phosphatase and ATPase on the folded plasma membranes at the basal part of the gland cells, and concluded that these elaborate membrane foldings might be involved in the transport of water and soluble substances to make watery sweat. Positive ATPase activity on the folded basal membranes of the axillary apocrine gland was also reported by BIEMPICA and MonTEs (1965).

The basal foldings of sweat glands thus have been believed to be involved in the production of a highly watery secretion from these glands. The morphological feature of the ceruminous gland provided with very poorly developed foldings as compared with the axillary apocrine gland may be reflecting the fact that the ceruminous gland produces a more or less dry secretion. In our previous report on the human axillary apocrine sweat gland, we demonstrated tiny vesicles aligned in rows at the base of the gland cell and assumed that these microvesicles might carry water from the base to the apical surface of the cell (Kurosumi et al., 1959). Munger (1965a, b) confirmed the occurrence of such a row of microvesicles continuous to the basal folded membranes, though he did not refer to any possible function of these forms. We did not observe them in our more recent studies on both eccrine and apocrine sweat glands of man and animals even where the basal foldings were conspicuous. We realize that the appearance of these microvesicles might be an artefact occurring during the specimen preparation, but it is not known which stage of preparation might be responsible for the formtion of such artefacts.

\section{ヒト外耳道アポクリン腺の透過および走査電子顕微鏡的研究}

I. 腺 細 胞

$$
\text { 黒 住一昌と川端 五十鈴 }
$$

ヒトの耳道腺 すなわち外耳道に分布するアポクリン汗腺を 透過および走査電子顕微鏡 で観察した.

腺細胞は非常によく発達した滑面小胞体とゴルジ装置を含有する.粗面小胞体はしぼし ぼ大きな球状の糸粒体に密に接近している。これらの大きな糸粒体注分泌顆粒と直接の関 係をもたない.ゴルジ層板の陥凹面の近くにいくつかの細管がタられる.これらのゴルジ 装置に附属した細管に特異な暗調物質が貯留し，大きな暗調分泌前顆粒を生ずる。その中 に多数の明調空胞が発生し，その表面から分離する．このようにして生じた空胞は，細胞 遊離表面の方に移動し，その内容を開口様式により放出する。これらの空胞のらちのいく つかは，細胞質のひきちぎり (分離)によっても腺腔に放出される，これはいわゆる離出 (アポクリン)分泌である. 
酸性ホスファターゼの活性は 暗調な分泌前顆粒にあらわれるのみならず, 細胞の先端部 に位置する明るい空胞や腺腔にも出現する。このような組織化学的所見は，アポクリン汗 腺の分泌物が ライソゾームに他ならない分泌前顆粒に由来する加水分解酵素をふくみ, こ れらの酵素が 離出分泌によって腺腔に放出された物質の 消化分解に資するものであろう ことを示唆する.

走査電子顕微鏡によって, いろいろな大きさのアポクリン分泌突起を腺腔表面に観察し た.

\section{References}

Bargmann, W., K. Fleischhauer und A. Knoop: Über die Morphologie der Milchsekretion. II. Zugleich eine Kritik am Schema der Sekretionsmorphologie. Z. Zellforsch. 53: 545-568 (1961).

Bargmann, W. und A. Knoop : Über die Morphologie der Milchsekretion. Licht- und elektronenmikroskopische Studien an der Milchdrüse der Ratte. Z. Zellforsch. 49: 344-388 (1959).

Bell, M.: The ultrastructure of human axillary apocrine glands after epinephrine injection. J. invest. Dermatol. 63: 147-159 (1974).

Biempica, L. and L. F. Montes: Secretory epithelium of the large axillary sweat glands. A cytochemical and electron microscopic study. Amer. J. Anat. 117: 47-72 (1965).

Caulfield, J. B. : Effects of varying the vehicle of $\mathrm{OsO}_{4}$ in tissue fixation. J. biophys. biochem. Cytol. 3: 827-830 (1957).

Charles, A.: An electron microscopic study of the human axillary apocrine gland. J. Anat. 93: 226-232 (1959).

Hashimoto, K., B. G. Gross and W. F. Lever: Electron microscopic study of apocrine secretion. J. invest. Dermatol. 46: 378-390 (1966).

Heath, E. : Cytologic observations on the secretory cells of the chin (submandibular) gland and brown inguinal gland in the rabbit. Cell Tiss. Res. 154: 399-408 (1974).

Hibbs, R. G.: Electron microscopy of human apocrine sweat glands. J. invest. Dermatol. 38: 7784 (1962).

Kawabata, I. : Electron microscope studies on the human ceruminous gland. Arch. histol. jap. 25: 165-187 (1964).

Kneeland, J. E.: Fine structure of the sweat glands of the antebrachial organ of Lemur catta. Z. Zellforsch. 73: 521-533 (1966).

Kurosumi, K.: Electron microscopic analysis of the secretion mechanism. Int. Rev. Cytol. 11: $1-124$ (1961).

- : In: (ed. by) Kanto Branch of Japanese Society of Electron Microscopy: Preparation techniques for electron microscopy (Japanese text). Tokyo, Seibundo-Shinkosha, 1970. (p. 303-304)

Kurosumi, K., T. Iijima and T. Kitamura : Electron microscopy of the human eccrine sweat gland with special reference to the folding of plasma membrane. In: Vierter Int. Kogr. Elektronenmikrosk. Berlin, Springer, 1960. (Bd. 2, S. 361-362)

Kurosumi, K. and T. Kitamura : Occurrence of foldings of plasma membrane ( $\beta$-cytomembrane) in cells of pig's carpal organ as revealed by electron microscopy. Nature 181: 489 (1958).

Kurosumi, K., T. Kitamura and T. Iijima : Electron microscope studies on the human axillary apocrine sweat glands. Arch. histol. jap. 16: 523-566 (1959).

Kurosumi, K., Y. Kobayashi and N. Baba : The fine structure of mammary glands of lactating rats, with special reference to the apocrine secretion. Exp. Cell Res. 50: 177-192 (1968).

Kurosumi, K., T. Matsuzawa and F. Saito: Electron microscopic observations on the sweat glands of the horse. Arch. histol. jap. 23: 295-310 (1963). 
Kurosumi, K., M. Yamagishi and M. Sekine: Mitochondrial deformation and apocrine secretory mechanism in the rabbit submandibular organ as revealed by electron microscopy. Z. Zellforsch. 55: 297-312 (1961).

Matsuzawa, T. and K. Kurosumi : The ultrastructure, morphogenesis and histochemistry of the sweat glands in the rat foot pads as revealed by electron microscopy. J. Electron Microsc. 12: 175-191 (1963).

Munger, B. L.: The cytology of apocrine sweat glands. I. Cat and monkey. Z. Zellforsch. 67: 373-389 (1965a).

- : The cytology of apocrine sweat glands. II. Human. Z. Zellforsch. 68: 837-851 (1965b).

Novikoff, A. B.: GERL, its form and function in neurons of rat spinal ganglia. Biol. Bull. 127: 358A (1964).

Novikoff, P. M., A. B. Novikoff, N. Quintana and J.-J. Hauw : Golgi apparatus, GERL, and lysosomes of neurons in rat dorsal root ganglia, studied by thick section and thin section cytochemistry. J. Cell Biol. 50: 859-886 (1971).

Schaumburg-Lever, G. and W. F. Lever : Secretion from human apocrine glands: An electron microscopic study. J. invest. Dermatol. 64: 38-41 (1975).

Sørensen, V. W. and G. Prasad: On the fine structure of horse sweat glands. Z. Anat. Entw.Gesch. 139: 173-183 (1973).

Takahashi, N.: Electron microscopic studies on the ectodermal secretory glands in man. I. The fine structures of the apocrine sweat gland, with special reference to the myoepithelium. Bull. Tokyo Med. Dent. Univ. 4: 259-269 (1957).

Yamada, H.: Electron microscopic observations on the secretory process of the axillary apocrine glands. Acta pathol. jap. 10: 173-187 (1960).

Yasuda, K., R. A. Ellis and W. Montagna: The fine structural relationship between mitochondria and light granules in the human apocrine sweat glands. Okajimas Fol. anat. jap. 38: 455-483 (1962).

黒住一昌

Т371 前橋市昭和町

群馬大学内分泌研究所

形態学研究部
Prof. Dr. Kazumasa Kurosumi

Department of Morphology

Institute of Endocrinology

Gunma University

Maebashi, 371 Japan 